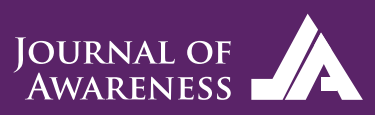

$\left(\begin{array}{l}0 \\ 0\end{array}\right)$

\title{
Government houses as presentation of power and ideology in the Ottoman State: The case of Safranbolu Government House
}

\author{
Sema Tuba Özmen ${ }^{1}$ \\ Beyza Onur ${ }^{2}$ \\ 1 M.Sc., Karabük University, Institute of Graduate Programs, Department of Architecture, Karabük, TURKEY, e-mail: sematubaozmen@gmail.com \\ 2 Assist. Dr., Karabük University, Faculty of Architecture, Department of Architecture, Karabük, TURKEY, e-mail: beyzaonur@karabuk.edu.tr
}

\begin{abstract}
Architecture, which is associated with the practice of producing space, has always rendered the powers and ideologies visible. This study investigates the government houses in the 19th century Ottoman State with regard to the notions of power and ideology and focuses on the Government House of Safranbolu. It is known that, in the specified period, government houses were important ideological interventions to urban space. This study aims to address the ideological context of the Safranbolu Government House, which is positioned with the ideal of the state. Based on this, first, the urban history of Safranbolu was examined. The importance of Safranbolu Government House in the history of the city, its relationship with the city, its ideological message to the city-dwellers and its architectural style were analyzed through a method based on archival research. All government houses of the period are the artifacts of urban-spatial structures and their architectural style as well as a shared ideology. Safranbolu Government House, which is one of the structures symbolizing the Ottoman State, was also built with a similar ideological consideration. Thus, the readability of the dominant ideology through the production style of Safranbolu Government House, one of the final period architectural artifacts of the Ottoman State, was verified.
\end{abstract}

Keywords: Ideology, power, architecture, government houses, Safranbolu Government House. 


\section{INTRODUCTION: POWER, IDEOLOGY AND ARCHITECTURE}

The notion of ideology, which is frequently discussed within the field of social sciences, gives room to a variety of discussions. One of these fields of discussion is on the close relationship established by the notion of ideology with architecture. Therefore, architecture should be seen not only as a building production activity, but also as a production of ideologies. Eagleton (1996: 17) described the polymorphism of the notion of ideology as "a text woven into a whole texture with different conceptual fibers". According to Mclellan (2005: $1-2)$; this term is an outcome of the social, political and intellectual changes brought by the Industrial Revolution. Ideology has generally been a concept that has a negative connotation. In addition to these definitions, Althusser's (2015: 77) main thesis is that "Ideology calls individuals as subjects; every ideology can exist only through a subject and for subjects". According to Mardin (2018: 129), the primary reasons for the spread of ideology to a great extent in the 19th and 20th centuries were: the emergence of new dissemination tools and new education systems to spread it, the growing importance of the intellectuals as an idea-generating class of the society, and the social events of the 19th century. As a result of all the definitions of ideology, the notion leaves its polysemy to the meaning of "the body of ideas defended by an individual or a community" that better fits the contemporary circumstances. Althusser (2015: 16-17) argues that there are two different forms of apparatus that he defines as the repressive and the ideological state apparatuses. In Althusser's taxonomy, the government, administration, army, police, courts, prisons, and etc. are the oppressive apparatus of the state.

In the context of the relationship between architecture and ideology, Gurallar Yeşilkaya (2003: 19) suggested that space can be considered as an ideological apparatus. In this regard, architecture under the monopoly of power can be influential. Political ideologies believe that they can be understood to the extent that they keep their sphere of influence as wide as possible. Therefore, these ideologies use various tools to expand their sphere of influence and to prevail. In line with this purpose, architecture's capability to respond to every ideological view through design has always made it attractive. Architecture is effective by designing the facts it aims to tell in accordance with the "response pattern" (Tanyeli,
1989) that contains a particular idea or a body of ideas. The relationship between architecture and ideology, in the sense we know it, has existed not only in the recent centuries, but since the centuries when architecture was first addressed within a social context. Throughout the ages, architecture has served ideologies as well as devising its own ideology. While each period embraces an ideology within its own, it also uses architecture by incorporating it. According to Göl (2009: 9-18), holders of the power employ ideology as a tool to maintain power. Power has an influence not only on people but also on the environment. Considering the types of ideologies, the ideologies that most seeks to reach the entire society is the political ones, therefore, political ideologies exerts a broader influence on the physical environment.

Also, according to Gurallar Yesilkaya (2003: 19), there are are two topics of discussion on the axis of architecture and ideology. The first of these; ideological architecture, is the using of architecture as a tool by political power. Here, space bears the signs of ideologies. The other subject is the ideology of architecture. It express the ideologies of architects belonging to their professional world. This distinction should not mean that professional ideologies are an autonomous field from the dominant ideology. Here, the place of the architect in this environment is the subject of investigation. Starting from these issues on the relationship between ideology and architecture, this study will focus on the subject of ideological architecture. Therefore, first of all, it is necessary to define the existing ideology in the 19th century Ottoman state, which constitutes the scope of the study.

\subsection{9th Century Ideology in the Ottoman State}

Among the changes in the Ottoman State starting from the 16th century and being performed potently in the 19th century, architecture had been an increasingly important field. Especially with the westernization practice adopted in the Tanzimat Period, the introduction of new institutions in the changing state organization, and the reformation of the former institutions in the Western style, a need for novel building types emerged. This need was met through the effective use of architecture. Political power, on the one hand, turned the some Tanzimat reforms into an architectural apparatus. Reforms initiated in the military field was completed with new architectural structures such as barracks, police stations and armaments, and bureauc- 
ratic developments followed with the opening of new government offices and agencies in the afterwards. The reflections of the aforementioned changes and the productive spaces of the power and ideology of the Ottoman rule were the government houses. The ideological reproduction as well as the images contributed by the government houses built in the post-Tanzimat period to the city and the architecture of the time constitute the framework of this study. Government houses built in the center and in the provinces, where official affairs were undertaken, also affected the formation of the cities. Government houses, revealing the visibility of the Tanzimat ideology in public structures in the Ottoman State, are a political component of the Tanzimat reforms. In this context, it is reasonable to suggest that government houses as one of the ideological machine, embody a rearrangement function of the public sphere.

The Tanzimat Reform Era of 19th century was an important step towards westernization and modernization in the Ottoman State. The reforms in this period were on the social and physical structure. The modern state focused on the production of new building types in cities, revised the education system and made changes in the military field. The Ottoman Westernization and Modernization processes in the 19th century were put into practice as a result of the necessities brought by the internal and external circumstances of the time (Ortayl1, 1985). After the declaration of the Imperial Edict of Tanzimat (Reorganization) in 1839, the notion of westernization became an ideology adopted by the state. The Tanzimat ideology was born out of a westernization effort, which was a continuation of the previous regulatory efforts. The basis of this ideology is reforms. Although these reforms were undertaken in order to regulate the deteriorating military order and to compensate the territorial losses, they later affected other areas as well (Ortaylı, 1985; Tanör, 1985). Akyürek (2008: 4-25) briefly discussed the Tanzimat process and the actors involved in this process: "On the whole, it is possible to speak of a transformation towards the notion of modern state. The role of the ruling elite, which claims to create and control this transformation, as one of the fundamental dynamics of the reconstruction process that all social mechanisms are exposed to in response to a disintegration from the traditional theological perception of the world, gains great importance in the same process."

In the Ottoman State, the removal of the zoning affairs from the organization of the imperial court began before the Tanzimat, in the time of Mahmud II. The 16th and the 19th century were the centuries where intense changes in the structures of Ottoman cities took place. In the 16th century, a classical Ottoman period, Ottoman cities were connected to a fortress structure, which consisted of two portions: the interior fortress and the exterior of it. There were no significant changes in the 17th and 18th centuries other than the fact that, due to the decreasing importance of the military class and the rise of the notables, the notables positioned closer to the center. In the 19th century, however, cities went through a remarkable transformation. The center located around the covered bazaar formed in the 16th century remained insufficient with regards to the new capitalist business relations of the 19th century, and a novel central business area necessitated by the new business connections emerged next to this center. With the bureaucratic environment introduced by the Tanzimat, state affairs started to be addressed not in the estates of military class members, but in government offices located in city centers. This change made state buildings a new point of attraction in city centers (Tekeli, 1985).

In the cities that started to be reshaped with the Tanzimat reforms, dead-end streets, the complex structure shaped around the mosque and the bazaar-market areas were affected. In this period of a demilitarized religion-based administration and architecture, of the Ottoman State who seeked to organize the cities and the urban life, the main purpose of the arrangements in the urban area was the centralization of the state, rather than being like the West. Westernization had simply been a tool for this end. Big cities were introduced in this period with the coal gas lamps illuminating the streets, regulations of construction, modern fire-fighting equipment and the launch of public transportation (Findley, 2011). Public structures built in certain areas in order to emphasize the centralized system emerged as ideological interventions to the urban space, and the state made the presence of Tanzimat ideology felt intensely by the urban dwellers in public spaces in the 19 th century.

In addition, one of the ideological interventions in the urban space in this period was the use of symbols of power. As symbols of symbolism, state ceremonies, changes in mosque architecture in line with modern protocol, and various symbolic manifestations such as coats of arms and insignia that reveal state power come 
to the fore. According to Deringil (2014: 34-35), the Ottoman symbols of power in the 19th century were divided into four categories. First, there were various symbols associated with the sanctity of the sultan's personality, such as the coat of arms in public buildings, ceremonies performed, official music and public affairs which directly reflected the glory and the power of the Ottoman State. Second are the specific and personal manifestations of state's generosity, such as the imperial standard and other ceremonial adornments. Religiously symbolic elements in the palace, such as calligraphy samples allegedly belonging to prominent figures of Islam or other materials of similar importance come in the third place. The fourth and the final category pertains to the linguistic symbolism in Ottoman official documentation. Certain phrases and words that often appear in official documents have provided valuable clues, although they are not always directly related to the person of the ruler.

This study explores the merge of political power with architecture in the process of westernization that came with the reforms of Tanzimat in the 19th century, through the Safranbolu Government House. In this context, Safranbolu Government House, built in Safranbolu district, which was an important hub of trade in the Ottoman State was deemed worth examining with its settling in the urban fabric and its representation of the state power. The study has been structured with a historical perspective based on archival research. First, the relationship between the notions of ideology and power, and architecture was provided through a literature review. Then, in the light of the aforementioned concepts, the architectural styles of the government houses in the Ottoman State and their settlings in the urban space were analyzed. Ottoman Archives of the Directorate of State Archives were scanned with particular reference to the Safranbolu Government House. Ideological context of the Safranbolu Government House, its location within the city, and its relationship with the city were discussed along with the city plans and building-scale visual materials.

\subsection{Literature Review}

Discussions on the ideology of the Tanzimat Period in the Ottoman State have been evaluated from various perspectives in the literature and have been the subject of numerous studies. Studies addressing the government houses in the Ottoman State are available in the literature. Neşe Gurallar Yeşilkaya, who produced significant works on the reading of ideology through architecture, introduced her graduate thesis titled "Ideology-Architecture Relationships and Community Center Buildings in Turkey: 1932-1946" in 1997, and introduced her book, "Community Centers: Ideology and Architecture" in 2003 as an extension of this study. In these studies, which have become a reference for multiple researches in the field of ideology and architecture, Gurallar Yeşilkaya argues that the community centers founded in the Republic Period successfully carried out the ideology, and defines these buildings as the structures that the government embodies its ideology in architecture by utilizing the representation power of architecture. Nurcan Yazıcı Metin's (2019) book titled "Gate of the State: The Construction Process and Architecture of Government Houses from Tanzimat to the Republic" is one of the most comprehensive sources prepared on this matter. In this book, which is the conclusion of a detailed research on the government houses, the author adds up her current research to the data she obtained on the government houses based on the light of the archive documents. The work evaluates the government houses in the context of ideology as well as the construction process and architecture. In Yasemin Avc1's (2017) book “Ottoman Government Houses: The Power and Representation of the State in the Urban Sphere in the Tanzimat Period", government houses are, again, examined as the representation of the power. While another comprehensive study that discusses the government houses with regard to power and representation, this study, the doctoral thesis of Neval Konuk Halaçoğlu (2018) titled “ Architectural Representation of Power and and Ideology in Government Houses in Ottoman Rumelia Villages (1839-1922)", examines the government houses in Rumeli region outside the borders of Turkey. The study addresses the history of the government houses discussed in the book, their urban-spatial setup and preferences of location, physical components of the space, and their post-Ottoman functions.

There are numerous studies in the literature examining government houses. However, among these studies, we have not encountered a study that examines and interprets the Safranbolu Government House within the history of the city and that addresses the transformation of the building into a natural element of the city of Safranbolu. Thus, the Safranbolu Government House, built in the fortress district, which is an important location in Safranbolu, was deemed worth examining in the 
context of the representation of the Ottoman ideology. The study, in this regard, aims to build its authenticity by focusing on Safranbolu. Another issue that this study aims to emphasize is the necessity of examining the history of Safranbolu city and the process of its urban formation. With all these aspects, this study intends not only to address Safranbolu Government House as an ideological production, but also to emphasize that the city comprises points worth exploring and illuminating through correct interpretations, and to indicate the significance of revealing how influential these values are in shaping the city.

\section{GOVERNMENT HOUSES IN THE 19TH CENTURY OTTOMAN STATE AND REPRESENTATION OF THE STATE}

Until the 19th century, it is not possible to mention the construction of a government house in order to carry out official affairs separately in the Ottoman State (Ortaylı, 1984; Yazıcı Metin, 2019: 30). Parallel to the changes occurring in the administrative structure, new elements emerged in the spatial structures of cities, one of them being the phenomenon of "administrative center". The "Government Houses" took place at the focal point of this administrative centers, which started to emerge in the 19th century (Aktüre, 1985). According to Yazıc1 Metin (2019: 181), in Ottoman correspondence, government houses were considered as "the criterion of development". The modernity of the cities has found a concrete expression in the language of architecture in the government houses. Since government houses could not be built rapidly in all settlements of the Ottoman State, the method of renting existing buildings, which were thought to be capable of serving new functions, was also used, which accelerated the bureaucratization process. It is known that this leasing process was sometimes funded by the contribution of the people, and public support was also received for building new houses. Another notable issue about houses is that these houses show particular changes according to the size of the settlement in which they are located. Thus, the largest and most spectacular built examples of government houses appear in large provincial centers. The houses built in the districts are known to be smaller in scale compared to the examples in the provinces. In addition to the size of the settlement, the government houses can stand out as featured structures in settlements on the pilgrimage route, important transportation networks or strategically important settlements.
As a result of the administrative regulations brought by Tanzimat, the construction of government houses in the sanjak, district and the subsequently formed sub-district units is regarded as a concrete ideological response to the desire of the central government to exhibit its presence in every corner under its rule (Yazıc1 Metin, 2019: 46-50).

Starting from the 19th century, the construction of government houses was attached great importance in the cities under Ottoman rule (URL1). Similarities are noticable in terms of the preferences of location, the structures built around the house, the overall architectural design setups and the symbolic forms used on the buildings. High hilltops or large and central areas within the city were generally preferred as the building site of the houses. Through these choices, the purpose of increasing the visibility of the power in the area where the houses are located was met (Figure 1).

Figure 1. Giresun Government House and Mardin Government House
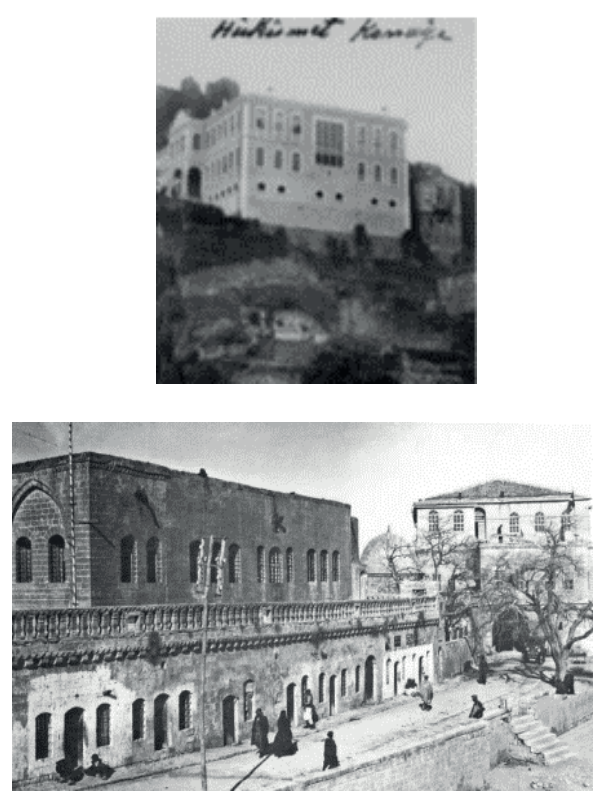

Source: URL2 and Düzenli, 2012

Buildings such as barracks, prison, courthouse, post office and clock tower could also be built in the vicinity of the government houses. Thus, government houses were simply transformed into a campus with their surroundings and became important representation centers of the period. These campuses also turned into city squares over time. This effort of integration, which Aktüre (1985) describes as the administrative center, can be seen either as in the example of Amasya government house (Figure 2) and its surrounding, which is not de- 
limited with any element, or in the form of campuses surrounded by castle walls to be built afterwards, as in the example of Edirne government house shown in Figure 3. These central campuses stand out with their high, wide entrance gates with power symbols on them, and their large gardens. Examples of these, include the garden Gates of Bilecik and Edirne government houses as shown in Figure 4. In government houses which are built on an entirely open field, emphasis was put on creating a large square, usually by the facade.

Figure 2. Amasya Government House Settlement (1- Government House, 2- Municipality Building, 3- Clock Tower, 4- Prison Building)

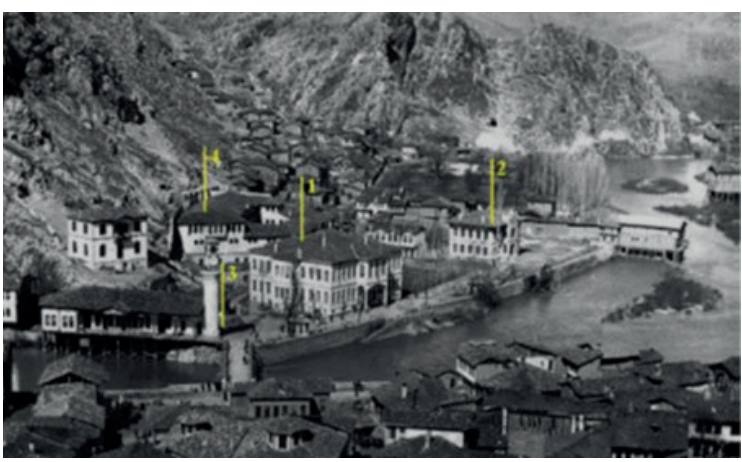

Source: URL3

Figure 3. Edirne Government House Settlement (1- Government House, 2- Provincial Printing House,

3- Post Office, 4- Courthouse, 5- Prison Building, 6- Gendarmerie)

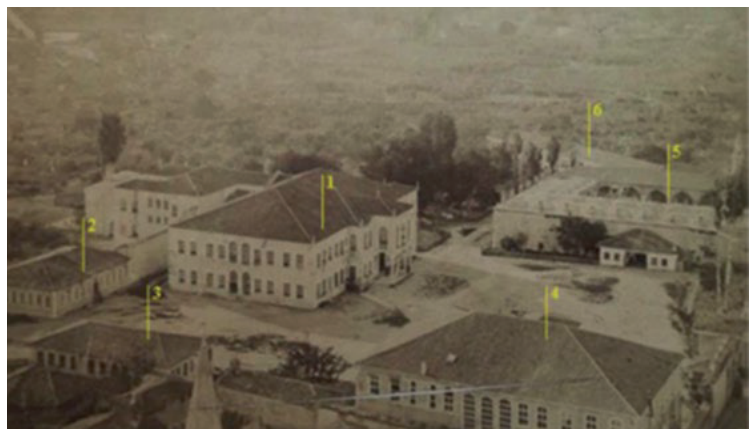

Source: URL4

Figure 4. Bilecik Government House and Edirne Government House's Garden Gate

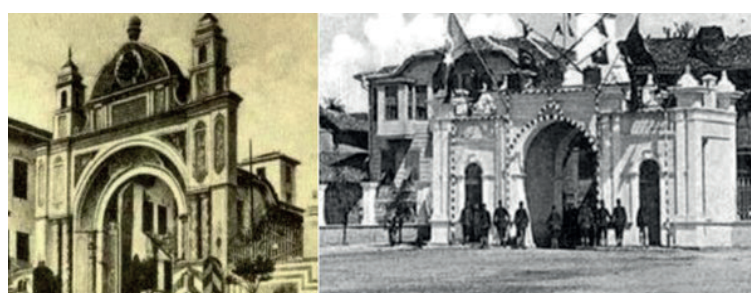

Source: Ortayl1, 1984; URL 5
Most of the government houses were built as a two-storey building on a high basement floor. Their facade designs are examples of a novel architectural formation for Ottoman architecture, with a neo-classical style. High entrance doors and high windows are items used in the new public building types of this period. On the entrance facade, examples with a pediment above the entrance are common. These pediments can either be triangular or in different forms. Symbols such as coats of arms, sultan's signatures and epitaphs, which are among the Ottoman symbols of power, were used on government houses as well as on the public buildings of the period. These symbols are engraved on important points, primarily on the entrance facade. The arms and sultan's signature, as symbols of power, are usually seen on the pediments and entrance doors in these houses. As Yazıcı Metin (2019: 185) states, the language of the inscriptions on the epitaphs usually located over the entrance door is symbolic. Examples include the government houses of Konya and Sinop with their architectures and symbols as shown in Figure 5.

Figure 5. Konya Government House and Sinop Government House

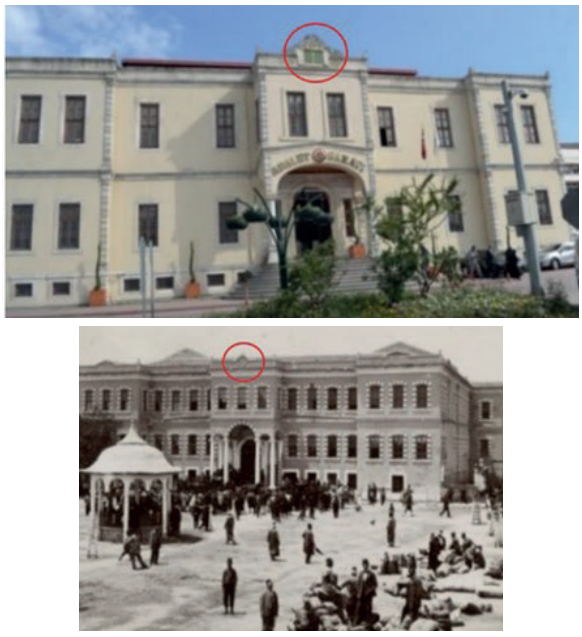

Source: URL6 and URL7

Government houses, besides the aforementioned basic architectural features, differed also with the influence of local elements. The focal point of the following part of the studyis the Safranbolu Government House with respect to the evaluation of it in the context of ideology and power concepts.

\section{CASE STUDY: SAFRANBOLU GOVERNMENT HOUSE}

The Safranbolu Government House is a surviving example of government houses built in Ottoman cities 
after the Tanzimat reforms as important elements of state representation. Built in harmony with the city and engraved in the memory of the city dwellers, it is the main administrative structure of the Ottomans in Safranbolu with its location. This government house, a late example of the government houses built starting from the years after the declaration of the Tanzimat, was built in 1905. Prior to discussing the government house, the administrative transformation of Safranbolu over time should be addressed to develop an understanding of the importance of the government house within the city.

\subsection{Urban History of Safranbolu}

Safranbolu, a settlement located in the Western Black Sea region of Turkey is today a district of Karabük province. The city went under Roman, Byzantine, Seljuk and Ottoman rule, respectively, and still bears certain traces of these periods. It is known that no urbanization took place in the region before 14th century. Its position as a strategically important border zone between Byzantium and Seljuk Empires led to continuous invasions and administrative changes. (Hacisalihoğlu, 1995: 43-45) (Figure 6). Until the 14th century, the Greek population in Safranbolu lived as a minority in the vicinity of Kıranköy, while Turks widely settled around the hills where the fortress is located, in the neighborhood called the marketplace (Çarşı; a.k.a. Çukur) today. It is understood that the settlement area expanded from the foothills of the fortress into the valley during this period (Hacısalihoğlu, 1995).

Figure 6. Safranbolu in the 14th Century

Figure 6. Safranbolu in the 14th Century

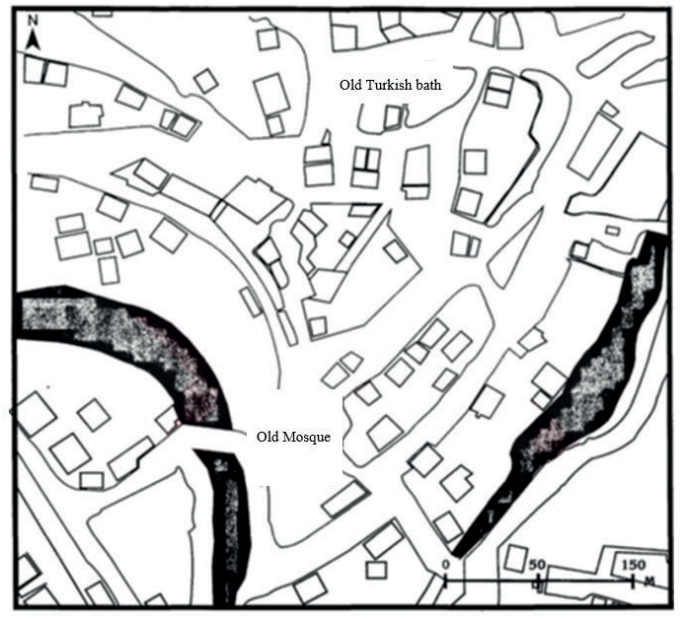

Source: Hacısalihoğlu, 1995: 128

Canbulat's (2020) work titled "Safranbolu in Travel
Book and Written Resources" reveals the administrative, social and cultural situation of Safranbolu over the past centuries. The travel book of Ibn Battuta (13041368), one of the important travelers of 14th century discussed in this work, covers important information about the composition of the city in that time. From the accounts of Ibn Battuta, it is understood that people who apparently had a say in the administrative organization of the city during this period, then under the rule of the Candaroğulları Principality, lived in the fortress. Hacısalihoğlu (1995) states that Safranbolu, with its surroundings, was "a settlement center with diversified economic activities shaped by its geographical conditions". This accounts for Safranbolu's rise to its important position for Ottoman trade after the century when it came under the rule of the Ottoman State. Safranbolu became a major market center after the initiation of urbanization. The primary reason for this is that it collected, processed and distributed the surplus products of its subordinate districts as an intermediary between the rural unit and the big city. Also, the development of commercial activities and the construction of the types of buildings in which these lines of activity can be carried out had parallels. Cinci Han, which was built in the middle of the 17th century, was apparently a large inn for Safranbolu as compared to the inns in other cities of the same period. This stems from the fact that Safranbolu was located on an important trade network in this period (Aktüre and Şenyapılı, 1976; Hacısalihoğlu, 1995). Hacısalihoğlu (1995) emphasizes that the elements of the Safranbolu city were constituted by the mosques, bazaars and Turkish baths, as is generally the case in most Islamic cities. Cinci Han, İzzet Mehmet Paşa Mosque, Kazdağlı Mosque, Köprülü Mehmet Paşa Mosque, Yeni Hamam (Cinci Hamam) and Arasta shops (Figure 7, Figure 8), the place correspond to these functions and act as the city center, can be regarded as an example of this. In this layout, the mosque constitutes the main center of the city, and other functions are shaped around the mosque. Thus, the mosque is the center of political, religious and cultural life. Since Turkish baths are meeting points like the mosques, they are located near the mosque in the central area. The potential of these areas to bring communities together enabled units such as market areas, arastas and inns to be shaped around these structures (Hacısalihoğlu, 1995: 134-135). 
Figure 7. Settlement of the Bazaar in Old Safranbolu

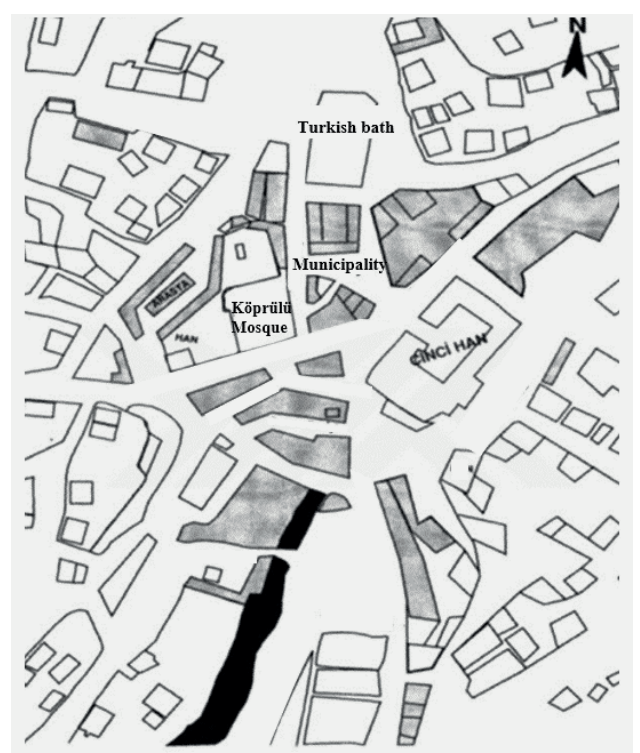

Source: Hacısalihoğlu, 1995: 136

Figure 8. Safranbolu Bazaar (1- Kazdağlı Mosque, 2-Turkish Bath, 3- Cinci Khan,

4- Köprülü Mehmet Pasha Mosque, 5- Arasta Shops)

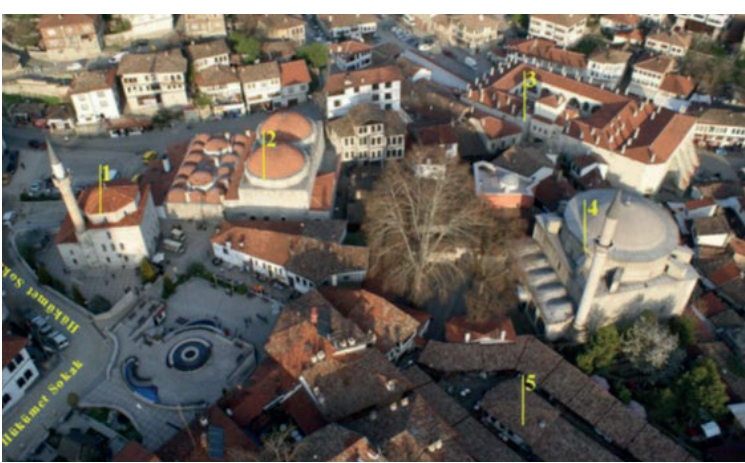

Source: URL6

When the Old Safranbolu map, which includes the Safranbolu Government House, is examined, the order in the old city can easily be read out. In the city, which remains within the natural boundary formed by the Gümüş and Akçasu streams flowing from north to south on both sides of the region, residential areas were established along the routes through which these water elements pass. The hilly area, where the old fortress is located and the Safranbolu Government House was built, rises from the bank of Gümüş Creek. On the east of this zone, there lay the areas with high potential of trade and settlement, which developed after the 17th century. Religious buildings and commercial buildings and areas are observed to have developed in this area, and residential areas were established on both sides of
Akçasu stream. With this settlement, the urbanization of Old Safranbolu was apparently complete (Figure 9).

Figure 9. Old Safranbolu Map

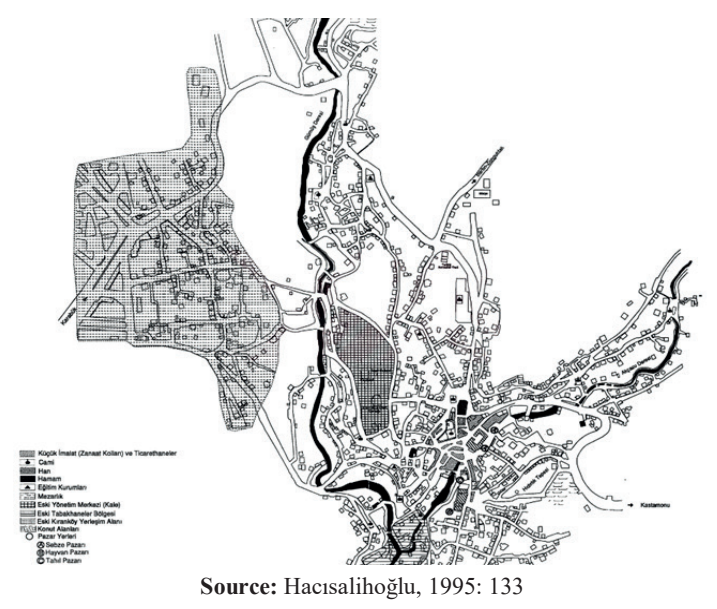

Source: Hacısalihoğlu, 1995: 133

\subsection{Traces of power and ideology in Safranbolu}

\section{Government House}

Safranbolu Government House has a high visibility in the old city of Safranbolu. In addition to being a structure where official affairs are carried out, it is also a structure of representation. It was built in the neo-classical style, which was the architectural style of the late Ottoman period. The buildings that integrate the concept of the administrative center dominate the silhouette of the city, which developed particularly after the 17th century, along with the Safranbolu Government House. According to the inscription on the originalepitaph, Safranbolu Government House was built in 1905. Ulukavak (2020: 5) states that this building was used as a prison between 1942 and 1950. The fortresses built on the highest point of the ruled territory were both important control points for better defense, and a manifestation of impassableness with their high and thick walls. In this context, the Government House is positioned as a campus with its surroundings, on the hilly area where the fortress was previously located. This campus included the Safranbolu Government House (1), an old mosque (2), a clock tower (3), a prison (4) and as a military building in its vicinity, a gendarmerie building (5). With this settlement, it is seen that the administrative center, which was aimed to be established in the context of the administrative order of the 19th century Safranbolu, was established in the fortress, and the units that were intented to be kept under control by the power were gathered here (Figure 10). 
Figure 10. Safranbolu Government House Campus (1Government House, 2- Masjid,

3- Clock Tower, 4- Prison, 5- Gendarmerie Building)

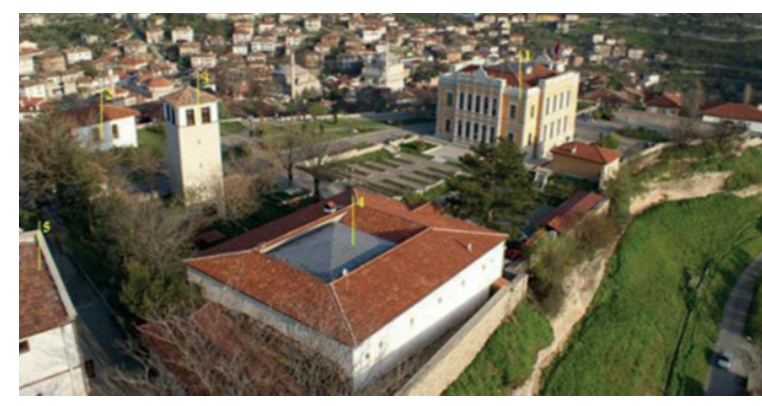

Source: URL7

Architectural structures, as forms of ideological intervention in urban space, are quite successful in maintaining their role. The readibility of the power is obvious in the location and the architectural formation of government house, which is one of the last period artifacts of the Ottoman State in the city. With its setup commanding the settlement, the house, which was built in the area called the fortress in the old settlement of Safranbolu, is in a position that can be easily seen from all angles around it (Figure 11). With the representation of this building, which has an important place in the urban history of Safranbolu, the visibility of the power in the now-ruined fortress became more clear. This location preference is still notable in our day. With this hilly area of the city preserving its military and administrative character throughout various periods, the building becomes a representational element without the need for additional effort.

Figure 11. The Location of the Safranbolu Government House in the City

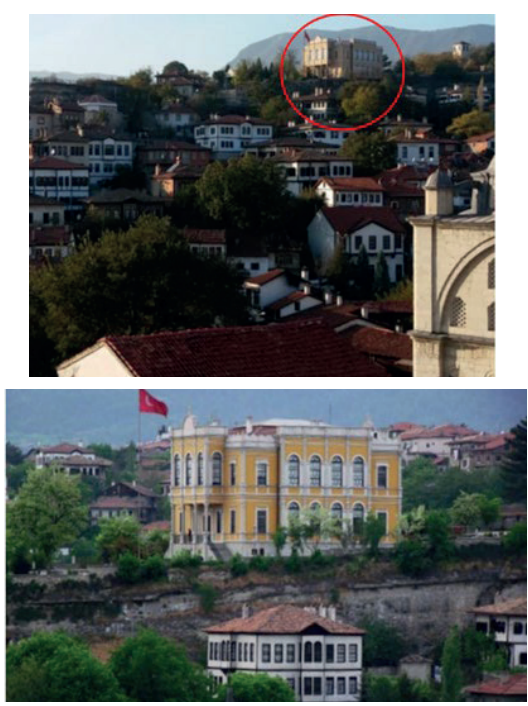

Source: Özmen, 2020
Political powers have the opportunity to manifest their power more vigorously on public spaces created by their own efforts. Public spaces can be "concrete ideological exhibitions of power" for both the people and foreign visitors by providing readability of the symbols of power in the public space setup, there may be squares intended for socialization, as well as areas such as hills and castle tops that can function as squares. Reforms brought by the Tanzimat in the Ottoman Empire were mostly realized in urban areas. In this context, the square seen on the facade of Safranbolu Government House emerges as an area with a public function (Figure 12).

Figure 12. Safranbolu Government House and Square
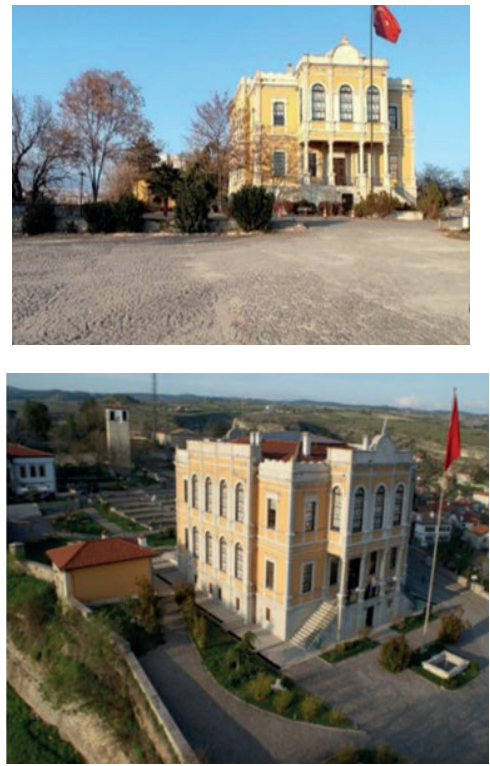

Source: Özmen, 2020

Considering its architectural features, this building emerges as a neo-classical style structure, which had become the classical architectural manner of the period and was frequently used in public buildings. The high entrance in the building with a square-like plan is provided by a double-arm staircase. On the facade, the colonnaded entrance is highlighted, making the entrance monumental. This emphasis is in the form of sub-column entrance of the neo-classical style, which was also used in the palace buildings of the period, and it increased the monumental appearance by making the size of the building more remarkable. There are protrusions in the middle sections of the rear front and both lateral facades, but they are not as distinct as they are on the facade. Especially the arched windows and the entrance door of the building are high in proportion to the 
building (Figure 13). These heights make the building look more magnificent. Another remarkable feature is the column alignments and floor moldings reflected on the facade. The monumental effect of the columns is enhanced by the continuation of the columns on the front facade in line with the column projections of the upper floor.

Figure 13. Safranbolu Government House Front Facade

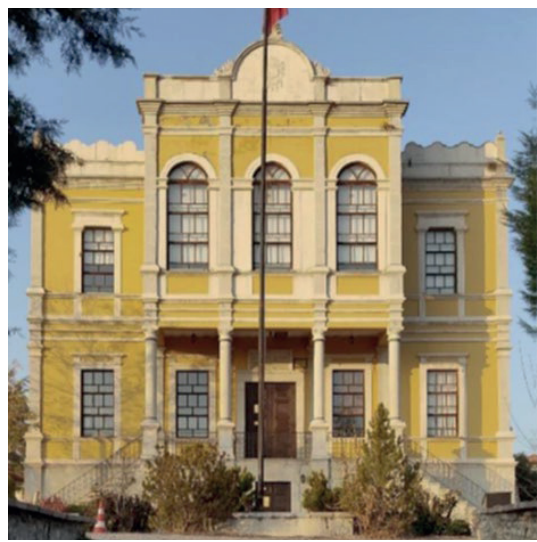

Source: Özmen, 2020

In the Safranbolu Government House campus, the height of the campus gate is also remarkable. In addition, the shape of the door has the same form as the facade pediment of the building, showing that every detail of this complex was given special attention and ostentation was important in every scale. It is seen that the symbols of power, which were frequently used in public buildings of the period, were also used on the house. There is an epitaph on the entrance door of the building, a coat of arms on the facade pediment, and a sultan's signature on the rear front pediment (Figure 14). In the last sentence inscribed on the epitaph of the building, it is stated that the building was built in accordance with the glory of the state. As can be understood from this inscription, the construction and architecture of the house was important for the government.
Figure 14. a) Safranbolu Government House Campus Entrance Door,

b) Inscription, c) Coat of Arms, d) Tugra

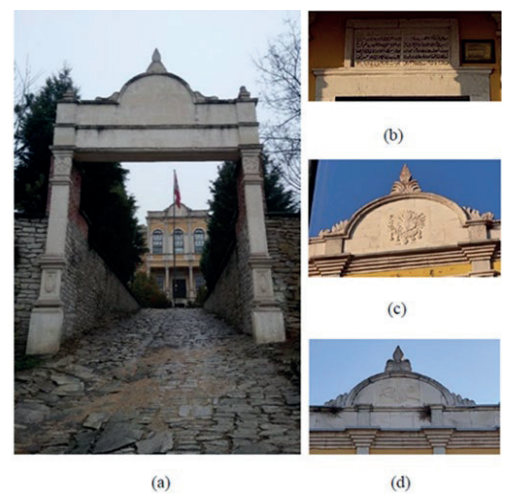

Source: Özmen, 2020

The plan scheme in some government houses created with references from traditional Turkish houses is similar to the formation of the rooms around the hall (Yaz1c1 Metin, 2019: 124). Such a formation is also evident in the Safranbolu Government House. The plan setup of the house was formed around the middle hall. Connection of the staircase connecting the ground floor and the first floor with double arms and its width enhances the effect of magnificence in the interior (Figure 15). The height of the floors, interior doors and windows of the building are remarkable, and it is understood that the power aims to look grand and magnificent with its architecture.

Figure 15. Ground and First Floor Plan
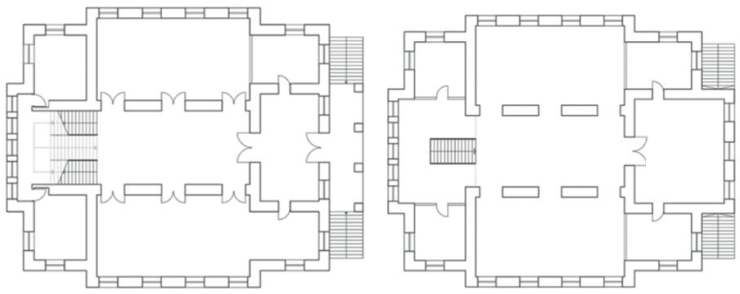

Source: Özmen, 2020

Safranbolu Government House became unusable in consequence a result of a fire in 1976 (URL7). As a result of the fire, the house lost its original wooden windows and doors, stairs, ceiling and floor coverings. The stone skeleton of the building, however, survived. The dated 1976 newspaper report seen in Figure 16 (Ulukavak, 2017: 175) and another newspaper article that presumably belongs to the same year, which is currently in the house, mention the outbreak of a fire in the house. These news also highlight the architectural value of 
the Government House and its significance for the city. Ulukavak (2017: 174) describes the the old fortress area damaged in this fire and the significance of the government house with the following words;

"Yes, not only our Government House, but our history was burnt, Safranbolu's Fortress was burnt. Fortress was the place where the State was represented for the people of Safranbolu; In the daily language of the people of Safranbolu, going up to the fortress was tantamount to going to the Government House for an affair. Safranbolu was left without its fortress."

From this interpretation, the public image of the house and the location chosen for the construction of the government house can be read out clearly. It is seen that the emphasis on state representation maintained its validity in the 20th century after the Ottoman Period.

Figure 16. a) The Newspaper Dated 1976, b) News from a Different Newspaper

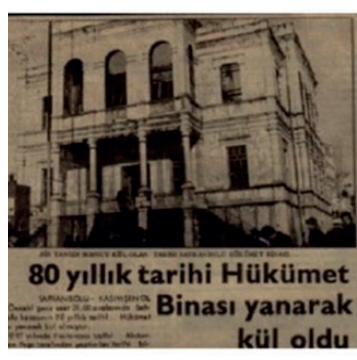

(a)

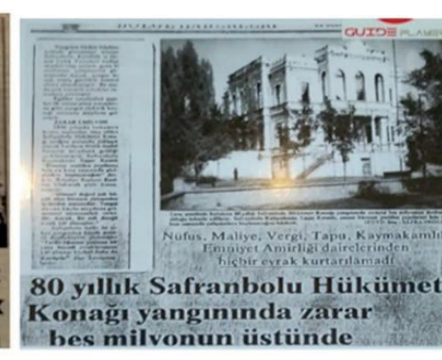

(b)
Source: Ulukavak, 2017: 175; City History Museum Information Board, 2020

In the campus of the Safranbolu Government House, there are also Safranbolu Clock Tower and the Old Prison, which are other elements of the administrative center. According to Acun (2011: 259), Safranbolu Clock Tower is one of the oldest clock towers in Anatolia. Safranbolu Clock Tower, located on the fortress in the government house campus, was built between 17941797 by Izzet Mehmet Pasha, the grand vizier of Selim III, who is from Safranbolu. As Halaç and Özdemir İlhan (2014) state: “Clock towers, which are generally the tallest buildings in the cities they were built, were placed next to important public buildings, in the squares that are the focal point or on the highest hill of the settlement. Clock towers, consitituting an urban image, are monuments, symbols and focal points that decorate cities and towns."

Safranbolu Clock Tower, which fits these definitions and was built in the castle before the government house as an important building type of the administrative center, demonstrates the demilitarization steps of the power. This structure, which is an important example of the initial period of demilitarization, is easily visible from all sides of the settlement. The Old Prison, located in the same campus, was built in 1906 during the time of Abdülhamit II. (Figure 17). The architectural design approach of the period prevails in the prison as a building controlled by the power.

Figure 17. Safranbolu Clock Tower and Safranbolu Old Prison

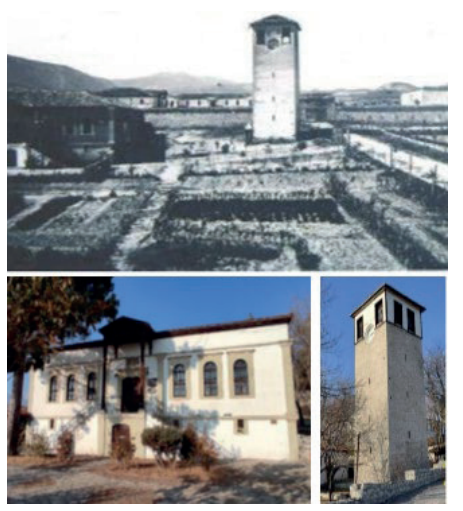

Source: URL8

\section{CONCLUSIONS}

The 19th century is the the time period for the Ottoman State, in which the process of change and transformation occured, and this process pioneered many innovations unlike the previous periods. The Tanzimat reforms, as the most influential period of the Westernization era, constituted the real turning point of these changes. With the Tanzimat period, the state ideology underwent a change as well. The Ottoman dynasty aimed to be visible and declare its existence on the lands under its rule. Therefore, the changes were not limited to the military and administrative sphere, but also reflected in the daily life. The political power started to pay attention to the representation of its power and visibility in various ways. Architectural activities, being the most convenient domain for concrete representation, gained speed with the Tanzimat; and architecture became a representational element of the power. It was observed that concrete architectural artifacts have an important place in the expression of the state power. Therefore, the political power found expression in the official structures of the state, especially in the palace structures, with its ideology, and reinforced this expression with various symbolic tools representing the 
sultan and the state. In the Ottoman State, the effect of the state ideology on the urban space and the building production process was seen in the government houses that emerged as an important manifestation of the late Ottoman ideology. During the Tanzimat period, where the state used all types of symbolic elements on a large or small scale as an ideological manifestation, the government houses shaped by ideology were the most prominent examples of this case. Government houses, in addition to being built in the neo-classical style, which is a specimen of westernization, formed an important administrative representation area with respect to the integrity they created with other building types located around them. For this, it was observed that the high hills commanding the city or large and central areas were preferred, aiming to reinforce the existence and domination of the state.

When the Safranbolu Government House is examined with the examples discussed, it is understood that the similarities in the government houses as a building typology differ according to the size of the settlement unit, the budget allocated to the building project, the use of local materials and local construction styles. The fact that Safranbolu Government House, which was evaluated in the context of ideology-power-architecture, became the symbol of the administrative presence in the city, took place as a consequence of the well-organization of the city of Safranbolu. It was the hilly area that formed a base for the current form of Safranbolu and started the initial settlement of the city with a military and administrative status. The commanding setup of this peak point, which started with the construction of the fortress, did not lose its importance until the 21st century. The castle, which was an important point in every period when the city passed in hands of various rules, was regarded as a starting point in the period of Ottoman rule, and it was seen that this area was used as an administrative and military zone.

Another noteworthy point with regards to the Safranbolu Government House, is the construction style which is addressed in the archive documents and emphasized in the epitaph of the building. In most of the government houses built by the Ottoman State, the method assumed for construction was resorting to the assistance of the people. When the epitaph of the Safranbolu Government House is examined, it is seen that the name of the governor of the time was inscribed on the epitaph as well as the phrase "built by helping one another." In this respect, Safranbolu Government House stands out as one of the rare examples where a local authority expressed its superiority. Deepening the discussion on the representation of political powers and ideologies through government houses, the form of construction, and manifestation of power to the people with the help of the people can provide more elaborate and qualified contributions to the literature.

\section{ACKNOWLEDGMENTS}

This paper was produced from the unpublished thesis titled "Government Houses as Presentation of Power and Ideology in the Ottoman State: The Case of Safranbolu Government House". It was prepared in the architectural program of the Institute of Graduate Studies of Karabuk University. Here, we would like to thank Karabuk University Scientific Research Projects Coordinator for supporting this study as the project coded "FYL- 2020- 2221".

\section{REFERENCES}

ACUN, H. (2011). Osmanlı Imparatorluğu Saat Kuleleri. Atatürk Kültür Merkezi Yayını, İstanbul.

AKYÜREK, G. (2008). Bilgiyi Yeniden Inşa Etmek: Tanzimat Dönemi Osmanlı Mimarlığı, Doktora Tezi, Yıldız Teknik Üniversitesi Fen Bilimleri Enstitüsü, İstanbul.

AKTÜRE, S. (1985). Osmanlı Devleti'nde Taşra Kentlerindeki Değişimler. Tanzimat'tan Cumhuriyet'e Türkiye Ansiklopedisi- Cilt 4, İletișim Yayınları, İstanbul.

AKTÜRE, S., \& ŞENYAPILI, T. (1976). Safranbolu'da Mekânsal Yapının Gösterdiği Nitelikler ve Koruma Önerilerinin Düşündürdükleri. O.D.T.Ü. Mimarlık Fakültesi Dergisi, 2(1), 61-96.

ALTHUSSER, L. (2015). İdeoloji ve Devletin İdeolojik Aygıtları (Çev. Alp Tümertekin). İthaki Yay. İstanbul.

AVCI, Y. (2017). Osmanlı Hükûmet Konaklart: Tanzimat Döneminde Kent Mekânında Devletin Erki ve Temsili. Tarih Vakfi Yurt Yayınları.

CANBULAT, İ. (2020). Seyahatname ve Yazılı Kaynaklarda Safranbolu. Safranbolu Çarşı'sı, 98-121.

DERINGİL, S. (2014). Iktidarın Sembolleri ve İdeoloji II. Abdülhamid Dönemi (1876-1909) (Çev: Gül Çağalı Güven), Doğan Kitap, İstanbul.

DÜZENLİ, H. İ. (2012). Mardin'de Tarih, Bina ve Mimarlık Katmanları: 19. yy. Hükümet Konağından 21. yy. Mimarlık Fakültesine Dönüșümün Hikâyesi. Arredamento Mimarlık, 254, 64-78.

EAGLETON, T. (1996). İdeoloji (Çev. Muttalip Özcan), Ayrıntı Yayınları, İstanbul.

FINDLEY, C. V. (2011). Tanzimat, Türkiye Tarihi Cilt IV-Modem Dünyada Türkiye 1839-2010. Kitap Yayınevi, İstanbul.

GÖL, B. (2009). Fiziksel Çevrede Egemen Ideoloji ve Direnç, Yüksek Lisans Tezi, İstanbul Teknik Üniversitesi Fen Bilimleri Enstitüsü, İstanbul. GURALLAR YEŞILKAYA, N. (2003). Halkevleri: Ídeoloji ve Mimarlık. 2. Baskı, İletișim Yayınları, İstanbul.

HACISALiHOĞLU, İ. Y. (1995). Sehir Coğrafyası Açısından Safranbolu- Karabük İkilemi, Doktora Tezi, İstanbul Üniversitesi Sosyal Bilimler 
Enstitüsü

HALAÇ, H. H., \& ÖZDEMIR İLHAN, S. (2014). Kentsel Imge Olarak Saat Kuleleri; II. Abdülhamit Han Dönemi Saat Kulelerinin İstanbul Dışı Türkiye Coğrafyasında Dağllımlarl ve Bir Tipoloji Denemesi, Humanities Sciences, 9(4), 190- 200.

KONUK HALAÇOĞLU, N. (2018). Tanzimat Sonrası, Osmanlı Rumeli Vilâyetleri Hükûmet Konaklarında Ideoloji ve Erk'in Mimari Temsili (18391922), Doktora Tezi, Atılım Üniversitesi Fen Bilimleri Enstitüsü, Ankara.

MARDİN, Ş. (2018). İdeoloji. İletişim Yayınları, İstanbul.

MCLELLAN, D. (2005). İdeoloji (Çev. Barış Yıldırım), İstanbul Bilgi Üniversitesi Yayınları, İstanbul.

ORTAYLI, İ. (1984). Söyleşi: Osmanlı'dan bugüne hükûmet konakları, Mimarlık, 22(5), 3-15.

ORTAYLI, İ. (1985). Batılılaşma Sorunu. Tanzimat'tan Cumhuriyet'e Türkiye Ansiklopedisi-Cilt 1, İletişim Yayınları, İstanbul.

TANÖR, B. (1985). Anayasal Gelişmelere Toplu Bir Baklş, Tanzimat'tan Cumhuriyet'e Türkiye Ansiklopedisi- Cilt 1, İletişim Yayınları, İstanbul.

TANYELİ, U. (1989). Mimarlıkta Ideolojik Amentü. Mimarlık, 27(4), 7881.

TEKELİ, İ. (1985). Tanzimat'tan Cumhuriyet'e Kentsel Dönüsüm. Tanzimat'tan Cumhuriyet'e Türkiye Ansiklopedisi- Cilt 4, İletişim Yayınları, İstanbul.

ULUKAVAK, K. (2017). Bir Safranbolulunun Penceresinden Safranbolu (Gözlemler-Derlemeler-Denemeler). Karabük Üniversitesi Yayınları, Karabük.

ULUKAVAK, K. (2020). Safranbolu- Korumada Tarihsel Süreç, Safranbolu Araştırmaları Merkezi Yayınları, İstanbul.

URL1. Tdv İslâm Ansiklopedisi (islamansiklopedisi.org.tr), Date of access: June, 2020.

URL2. Salt Araştırma: Giresun Hükümet Konağı- Giresun City Hall (saltresearch.org), Date of access: November, 2020.

URL3. Amasya | Eski Türkiye Fotoğrafları Arşivi (eskiturkiye.net), [Date of access: November 2020].

URL4. Edirne, 1878 | Eski Türkiye Fotoğrafları Arşivi (eskiturkiye.net), [Date of access: November, 2020].

URL5. Edirne Paşakapısı / 1900'ler | Eski Türkiye Fotoğrafları Arşivi (eskiturkiye.net), [Date of access: November, 2020].

URL6. http://karabuk.gov.tr/safranbolu-ilcesi, [Date of access: November, 2020].

URL7. Kent Tarihi Müzesi (ktb.gov.tr), [Date of access: November, 2020]. URL8. Kent Tarihi Müzesi Ve Tarihi Saat Kulesi (ktb.gov.tr), [Date of access: November, 2020].

YAZICI METIN, N., 2019, Tanzimat'tan Cumhuriyet'e Hükûmet Konaklarının İnșa Süreci ve Mimarisi Devlet Kapısı, Kitabevi, İstanbul. 